\title{
Research on design parameters of double hole corrugated pipe culvert
}

\author{
Chengying Hao', a, Liquan Liu, ${ }^{2, b}$, Zhihong Wang ${ }^{3,}$ cand Shui Wan ${ }^{4, d}$
}

\author{
${ }^{1}$ China Communications Construction Second Highway Consultants Co.Itd, Wuhan, China \\ ${ }^{2}$ Hebei expressway rongwu management office, Hebei,China \\ ${ }^{3}$ Hengshui Yitong Pipe Industry Co.Ltd, Hengshui ,China \\ ${ }^{4}$ School of Transportation, Southeast University, Nanjing, China \\ a10507254@qq.com, brwgszgb@163.com, c361158663@qq.com, dlanyu421@163.com
}

\section{Keywords: parameter;bellows;simulation; deformation; stress}

Abstract. The bellows is a flexible force structure. When a parameter of corrugated pipe is changed, the force and deformation of the pipe are changed. With double hole Steel corrugated pipes as the background, this paper adopted finite element analysis software ANSYS to make numerical simulation of the study. The force and deformation properties of the bellows are analysed from pipe diameter, wavelength and plate thickness. The stability rule of corrugated pipe culvert is studied.

\section{Introduction}

When a parameter of the corrugated pipe is changed, the force and deformation of the bellows will change. The change of the force and deformation of the corrugated pipes when a parameter changes after construction is obtained by the finite element models. Therefore, the stability rule can be analyzed and the feasibility improvement measures can be put forward to analyze the effect of various improvement measures. The reasonable waveform and plate thickness are studied.

\section{The Research Methods}

Finite Element Modeling. Finite element software ANSYS was used for modeling and analysis. The initial bellows parameter is $6 \mathrm{~m}$, and the corrugated form is $400 \mathrm{~mm} \times 150 \mathrm{~mm}$, i.e., the wave distance is $400 \mathrm{~mm}$ and the wave height is $150 \mathrm{~mm}$. Symmetrical loading is applied with symmetrical modeling method. Choosing the right boundary as the symmetry plane. The thickness is $6.5 \mathrm{~mm}$, and the left margin of the corrugated pipe is $9 \mathrm{~m}$ and $0.75 \mathrm{~m}$ from the right side, i.e. $1.5 \mathrm{~m}$ between the two tubes. Four basic wavelengths are selected on the axis. The height of the foundation is $9 \mathrm{~m}$, and The highest fill is 8 meters. The boundary conditions of the soil are assumed to be a chain bar bearing only the $\mathrm{x}$ direction of the left boundary. And the right boundary is symmetric. The ground surface is assumed to be the fixed end boundary condition. The structural finite element model is shown in figure 1 . The parameters of soil and bellows are shown in table 1.

\begin{tabular}{|c|c|c|c|}
\hline TABLE & & parameters & he model \\
\hline Parameters & $\begin{array}{l}\text { The steel } \\
\text { plate }\end{array}$ & Backfill soil & Foundation \\
\hline $\begin{array}{l}\text { Modulus of } \\
\text { elasticity } \\
(\mathrm{MPa})\end{array}$ & $2.1 \mathrm{E}+5$ & 60 & 200 \\
\hline $\begin{array}{l}\text { Poisson's } \\
\text { ratio }\end{array}$ & 0.3 & 0.3 & 0.25 \\
\hline $\begin{array}{l}\text { density } \\
(\mathbf{k g} / \mathbf{m}[\stackrel{L}{)})\end{array}$ & $7.85 \mathrm{E}+3$ & $1.8 \mathrm{E}+3$ & $2.2 \mathrm{E}+3$ \\
\hline $\begin{array}{l}\text { Cohesive } \\
\text { force }\end{array}$ & 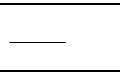 & 28 & 44 \\
\hline $\begin{array}{l}\text { Angle of } \\
\text { internal }\end{array}$ & 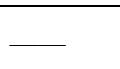 & 21 & 25 \\
\hline
\end{tabular}

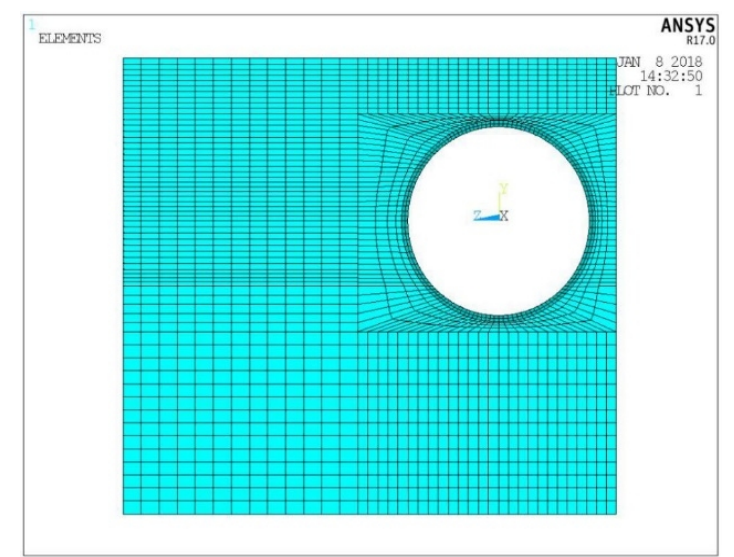

Fig 1. Figure of the finite element model 
All the research is based on the situation that completion of the filling that the total filling height is $8 \mathrm{~m}$. It is assumed that the deformation and force of the left and right tubes are the same. The stress and deformation of the number 1,2,3,4,5 and 7 points on the left tube are selected to reflect the stress and shape changes of the structure. The specific location of the test point is shown in figure 2 below.

\section{Pipe Diameter Parameter Analysis}

When the pipe diameter of the corrugated pipe is changed, the force and deformation of the bellows will change. We maintain the soil parameters, the other parameters of the corrugated pipe are unchanged, but only the diameter of the pipe is changed to study on the influence of the pipe diameter on the force and deformation of the corrugated pipes.

Deformation Analysis. When the filling height is $8 \mathrm{~m}$, the vertical and horizontal deformation of the left pipe is as follows. The deformation value is the difference between pipe diameter under load and initial pipe diameter. We assume the distance between test point 1 and test point 5 is L1 and the distance between test point 3 and test point 7 is L2. The vertical deformation value is the difference between L1 and initial pipe diameter $\mathrm{d}$. The horizontal deformation value is the difference between L2 and initial pipe diameter d. We can see clearly on figure 3 .

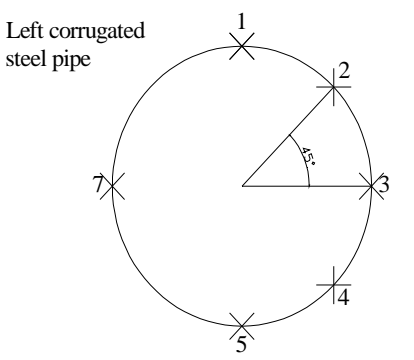

Fig 2. Figure of layout of test points

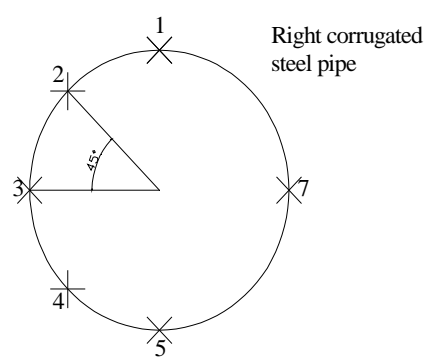

Fig 3. The vertical and horizontal deformation diagram of the bellows

The vertical and horizontal deformation of the left pipe of different pipe diameters is shown in table 2 and figure 4. Vertical deformation up is "+", downward is "-"and horizontal deformation to the left is "+", to the right is "-".

TABLE 2 The vertical and horizontal deformation values of the left pipe of different pipe diameters $(\mathrm{mm})$

\begin{tabular}{|c|l|l|l|l|l|}
\hline $\begin{array}{c}\text { Bellows } \\
\text { diameter( } \\
\text { m) }\end{array}$ & 1 & 1.5 & 3 & 6 & 8 \\
\hline $\begin{array}{c}\text { Vertical } \\
\text { deformatio } \\
\text { n value }\end{array}$ & 2.13 & 2.45 & 3.16 & 4.02 & 4.61 \\
\hline $\begin{array}{c}\text { Horizontal } \\
\text { deformatio } \\
\text { n value }\end{array}$ & -0.34 & -0.42 & -0.78 & -1.30 & -1.64 \\
\hline
\end{tabular}

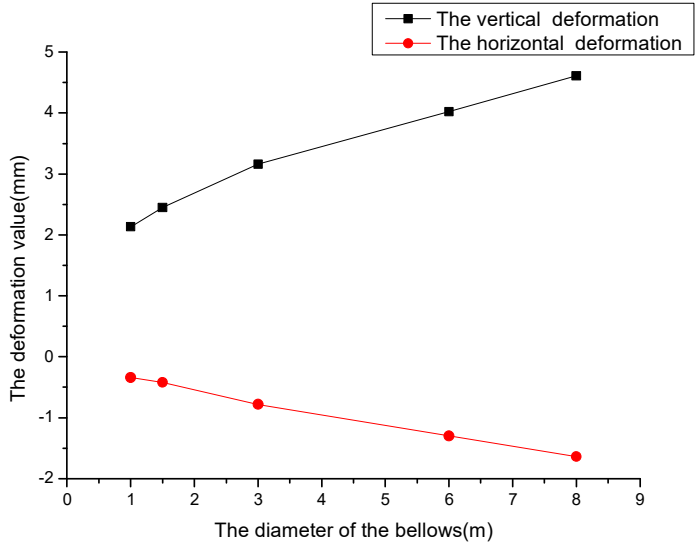

Fig 4. The vertical and horizontal deformation of the left pipe of different pipe diameters $(\mathrm{mm})$

As we can see from the diagram, with the increase of pipe diameter, the absolute value of the vertical and horizontal deformation increases. In addition, the rate of the increase decreases when the diameter become larger. 
Tangential Stress Analysis. The tangential stress of the wave crests and troughs positions calculated of different pipe diameters is shown in table 3 , table 4 and figure 5 below. The tensile stress of tangential stress is "+" and compressive stress is "-"

TABLE 3 The tangential stress values of each measuring point of the wave crest of different pipe diameters

\begin{tabular}{|l|l|l|l|l|l|l|}
\hline $\begin{array}{c}\text { Bellows } \\
\text { diameter( } \\
\mathbf{m})\end{array}$ & $\begin{array}{l}\text { Test } \\
\text { point } \\
\mathbf{1}\end{array}$ & $\begin{array}{l}\text { Test } \\
\text { point } \\
\mathbf{2}\end{array}$ & $\begin{array}{l}\text { Test } \\
\text { point } \\
\mathbf{3}\end{array}$ & $\begin{array}{l}\text { Test } \\
\text { point } \\
\mathbf{4}\end{array}$ & $\begin{array}{l}\text { Test } \\
\text { point } \\
\mathbf{5}\end{array}$ & $\begin{array}{l}\text { Test } \\
\text { point } \\
\mathbf{7}\end{array}$ \\
\hline 1 & 1.62 & -0.11 & -5.36 & -0.19 & 1.62 & -2.98 \\
\hline 1.5 & 3.14 & -0.62 & -8.74 & -0.62 & 2.13 & -4.63 \\
\hline 3 & 4.62 & -1.39 & -11.09 & -1.09 & 3.01 & -6.52 \\
\hline 6 & 5.6 & -1.81 & -12.44 & -1.45 & 3.49 & -7.32 \\
\hline 8 & 6.64 & -2.32 & -13.65 & -1.81 & 4.07 & -8.06 \\
\hline
\end{tabular}

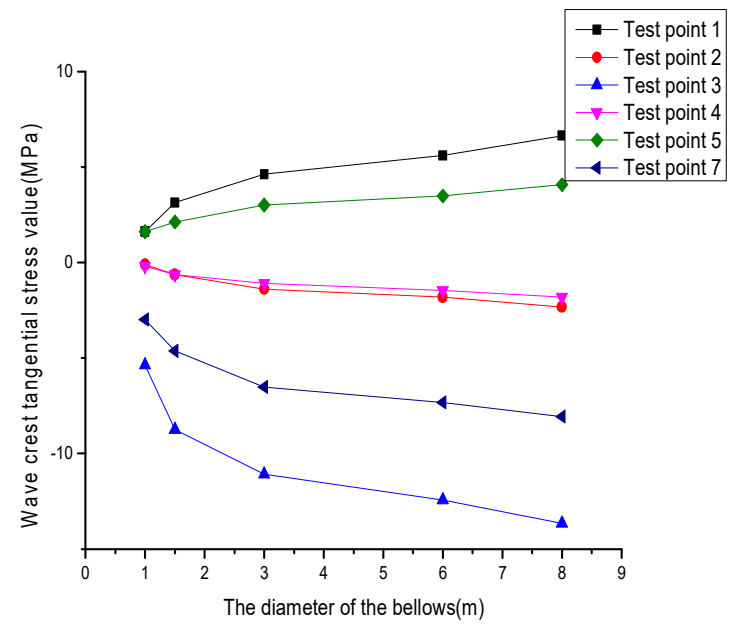

(a)
TABLE 4 The tangential stress values of each measuring point of the wave trough of different pipe diameters

\begin{tabular}{|l|l|l|l|l|l|l|}
\hline $\begin{array}{c}\text { Bellows } \\
\text { diameter( } \\
\mathbf{m})\end{array}$ & $\begin{array}{l}\text { Test } \\
\text { point } \\
\mathbf{1}\end{array}$ & $\begin{array}{l}\text { Test } \\
\text { point } \\
\mathbf{2}\end{array}$ & $\begin{array}{l}\text { Test } \\
\text { point } \\
\mathbf{3}\end{array}$ & $\begin{array}{l}\text { Test } \\
\text { point } \\
\mathbf{4}\end{array}$ & $\begin{array}{l}\text { Test } \\
\text { point } \\
\mathbf{5}\end{array}$ & $\begin{array}{l}\text { Test } \\
\text { point } \\
\mathbf{7}\end{array}$ \\
\hline 1 & -1.62 & 1.21 & 1.32 & 1.03 & -1.13 & 2.96 \\
\hline 1.5 & -2.41 & 1.63 & 2.00 & 1.54 & -1.78 & 3.89 \\
\hline 3 & -3.32 & 2.21 & 2.69 & 2.01 & -2.45 & 4.88 \\
\hline 6 & -3.78 & 2.55 & 3.10 & 2.35 & -2.86 & 5.33 \\
\hline 8 & -4.12 & 2.83 & 3.54 & 2.53 & -3.27 & 5.79 \\
\hline
\end{tabular}

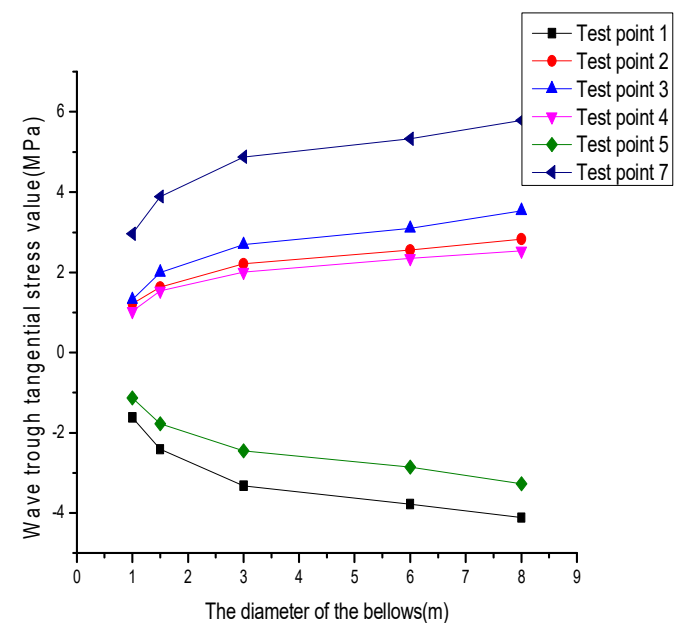

(b)

Fig 5. Figure of the tangential stress of each measuring point of the wave crest (a) and though(b) of different pipe diameters

It can be seen from the figure that with the increase of pipe diameter, the absolute value of tangential stress of each test point at the position of the left bellows is increasing. The maximum compressive stress is at point 3 of the crest, the maximum tensile stress is at point 1 . The maximum compressive stress is at point 1 of the trough, and the maximum tensile stress is at point 7 . When the pipe diameter is less than $3 \mathrm{~m}$, the growth rate of the tangential stress of the wave crest is faster. When the pipe diameter was greater than $3 \mathrm{~m}$, the growth rate of the tangential stress of the wave crest was relatively slow. It shows that the large diameter bellows removing part of the filled soil load, which has direct effects on culvert structure of load decreases, and lead to corrugated pipe culvert tangential stress value increase has slowed.

\section{Wavelength Parameter Analysis}

Deformation analysis. When the filling height is $8 \mathrm{~m}$, the vertical and horizontal deformation values of the left pipe of different wavelength is shown in table 5 and figure 6. 
TABLE 5 The vertical and horizontal deformation values of the left pipe of different wavelengths $(\mathrm{mm})$

\begin{tabular}{|c|l|l|l|l|l|l|}
\hline $\begin{array}{c}\text { Bellows } \\
\text { wavelength(mm } \\
\text { ) }\end{array}$ & 150 & 200 & 250 & 300 & 350 & 400 \\
\hline $\begin{array}{c}\text { Vertical } \\
\text { deformation } \\
\text { value }\end{array}$ & 2.55 & 2.84 & 3.16 & 3.43 & 3.71 & 4.02 \\
\hline $\begin{array}{c}\text { Horizontal } \\
\text { deformation } \\
\text { value }\end{array}$ & -0.78 & -0.84 & -0.97 & -1.04 & -1.18 & -1.30 \\
\hline
\end{tabular}

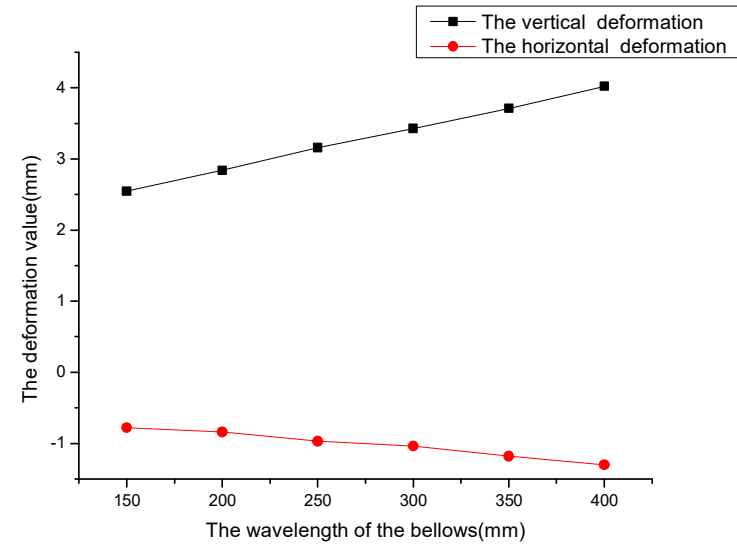

Fig 6. Figure of the vertical and horizontal deformation of the left pipe of different wavelengths $(\mathrm{mm})$

As we can see from the diagram, with the increase of the wavelength, the absolute value of the vertical and horizontal deformation value of the corrugated pipes is linearly increasing. This is because long or shallow corrugated tube stiffness is small while short or deep corrugated pipe stiffness is large.

Tangential stress analysis. The tangential stress of the wave crests and troughs positions calculated of different wavelengths is shown in table 6 , table 7 and figure 7 below.

TABLE 6 The tangential stress values of each measuring point of the wave crest of different wavelengths $(\mathrm{MPa})$

\begin{tabular}{|c|c|c|c|c|c|c|}
\hline $\begin{array}{c}\text { Bellows } \\
\text { wavelength(m } \\
\mathbf{m})\end{array}$ & $\begin{array}{c}\text { Test } \\
\text { point } \\
\mathbf{1}\end{array}$ & $\begin{array}{c}\text { Test } \\
\text { point } \\
\mathbf{2}\end{array}$ & $\begin{array}{c}\text { Test } \\
\text { point } \\
\mathbf{3}\end{array}$ & $\begin{array}{c}\text { Test } \\
\text { point } \\
\mathbf{4}\end{array}$ & $\begin{array}{c}\text { Test } \\
\text { point } \\
\mathbf{5}\end{array}$ & $\begin{array}{c}\text { Test } \\
\text { point } \\
\mathbf{7}\end{array}$ \\
\hline 150 & 1.33 & -0.43 & --2.9 & -0.34 & 0.83 & -1.74 \\
\hline 200 & 1.77 & -0.57 & -3.9 & -0.46 & 1.10 & -2.32 \\
\hline 250 & 2.36 & -0.76 & -5.2 & -0.61 & 1.47 & -3.09 \\
\hline 300 & 3.15 & -1.02 & -6.9 & -0.82 & 1.96 & -4.12 \\
\hline 350 & 4.20 & -1.36 & -9.3 & -1.09 & 2.62 & -5.49 \\
\hline 400 & 5.60 & -1.81 & -12.4 & -1.45 & 3.49 & -7.32 \\
\hline
\end{tabular}

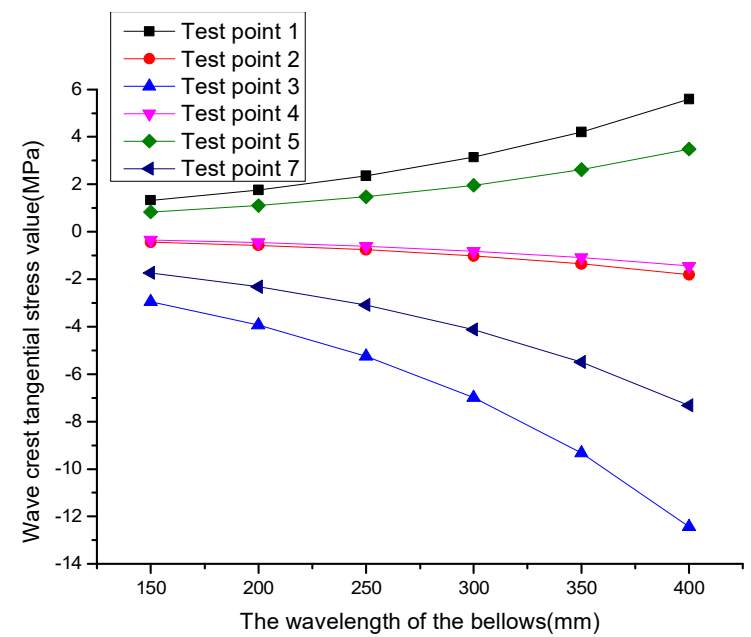

(a)
TABLE 7 The tangential stress values of each measuring point of the wave trough of different wavelengths $(\mathrm{MPa})$

\begin{tabular}{|c|c|c|c|c|c|c|}
\hline $\begin{array}{c}\text { Bellows } \\
\text { wavelength(m } \\
\text { m) }\end{array}$ & $\begin{array}{c}\text { Test } \\
\text { point } \\
\mathbf{1}\end{array}$ & $\begin{array}{c}\text { Test } \\
\text { point } \\
\mathbf{2}\end{array}$ & $\begin{array}{c}\text { Test } \\
\text { point } \\
\mathbf{3}\end{array}$ & $\begin{array}{c}\text { Test } \\
\text { point } \\
\mathbf{4}\end{array}$ & $\begin{array}{c}\text { Test } \\
\text { point } \\
\mathbf{5}\end{array}$ & $\begin{array}{c}\text { Test } \\
\text { point } \\
\mathbf{7}\end{array}$ \\
\hline 150 & -0.92 & 0.62 & 0.71 & 0.56 & -0.64 & 1.34 \\
\hline 200 & -1.24 & 0.81 & 0.99 & 0.75 & -0.90 & 1.69 \\
\hline 250 & -1.68 & 1.21 & 1.27 & 0.96 & -1.18 & 2.16 \\
\hline 300 & -2.04 & 1.31 & 1.71 & 1.41 & -1.57 & 3.01 \\
\hline 350 & -2.71 & 1.94 & 2.41 & 1.76 & -2.15 & 3.99 \\
\hline 400 & -3.78 & 2.55 & 3.10 & 2.35 & -2.86 & 5.33 \\
\hline
\end{tabular}

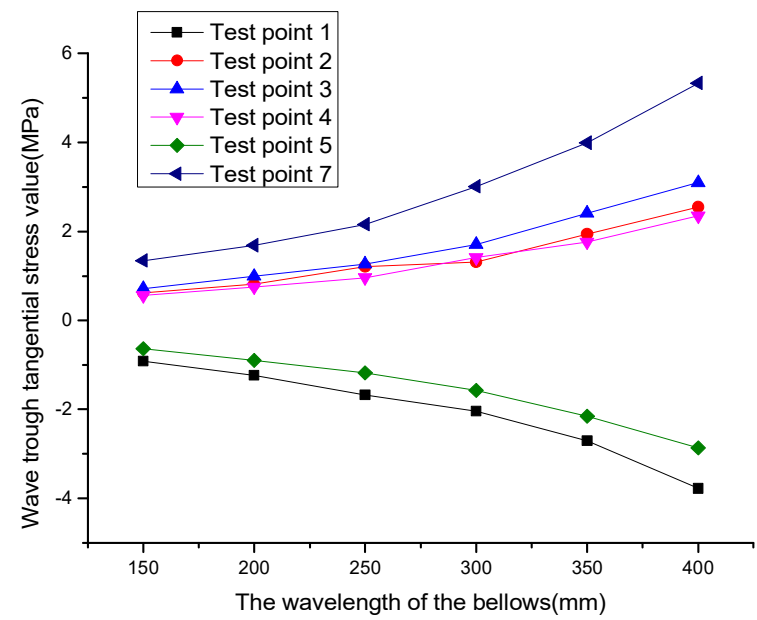

(b)

Fig 7. Figure of the tangential stress of each measuring point of the wave crest(a) and tough(b) of different wavelengths

Figure 7 shows that with the increase of wavelength, the absolute value of the tangential stress of corrugated pipe is linearly increasing. The change of the wave crest is smaller than that of the trough. The longer the wavelength is, the larger the contact area between the corrugated pipe structure and 
the soil is, and the ripple effect will be reduced when the filling load is applied, as the result the culvert will increase the stress, which is not conducive to the culvert structure.

\section{Plate Thickness Parameter Analysis}

When the thickness of the corrugated pipe is changed, the force and deformation of the bellows will change. We maintain the soil parameters, the other parameters of the corrugated pipe are unchanged, but only the thickness of the pipe is changed to study on the influence of the thickness on the force and deformation of the corrugated pipe.

Deformation analysis. When the filling height is $8 \mathrm{~m}$, the vertical and horizontal deformation of the left pipe of different thickness is shown in table 8 and figure 8.

TABLE 8 The vertical and horizontal deformation values of the left pipe of different thickness $(\mathrm{mm})$

\begin{tabular}{|c|l|l|l|l|l|l|}
\hline $\begin{array}{c}\text { Bellows } \\
\text { thickness(mm) }\end{array}$ & 4 & 5 & 6 & 7 & 8 & 9 \\
\hline $\begin{array}{c}\text { Vertical } \\
\text { deformation } \\
\text { value }\end{array}$ & 9.17 & 7.24 & 5.14 & 3.01 & 1.21 & 0.43 \\
\hline $\begin{array}{c}\text { Horizontal } \\
\text { deformation } \\
\text { value }\end{array}$ & -3.14 & -2.56 & -1.76 & -0.91 & -0.24 & -0.1 \\
\hline
\end{tabular}

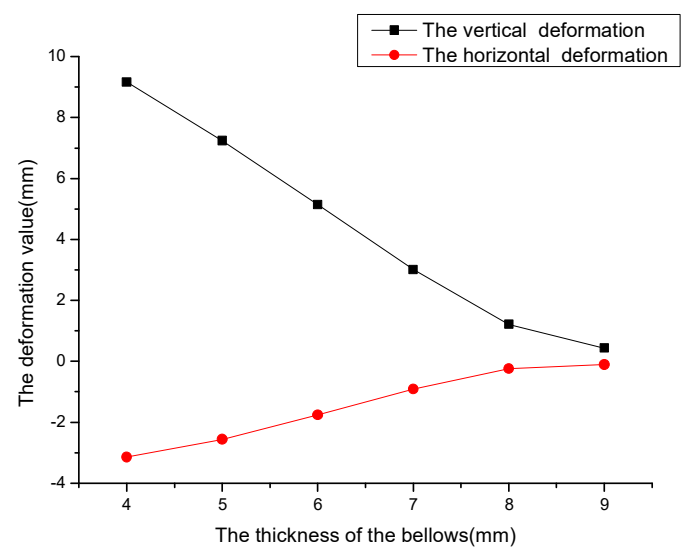

Fig 8. The vertical and horizontal deformation of the left pipe of different thickness when the filling is completed(mm)

We can summarize from the diagram that with the increase of the thickness of the corrugated pipe, the absolute value of the deformation of steel corrugated pipe is significantly reduced. It is shown that the deformation of bellows can be controlled effectively by increasing the thickness of bellows.

Tangential stress analysis. The tangential stress of the wave crests and troughs positions calculated of different thickness is shown in figure 9 below
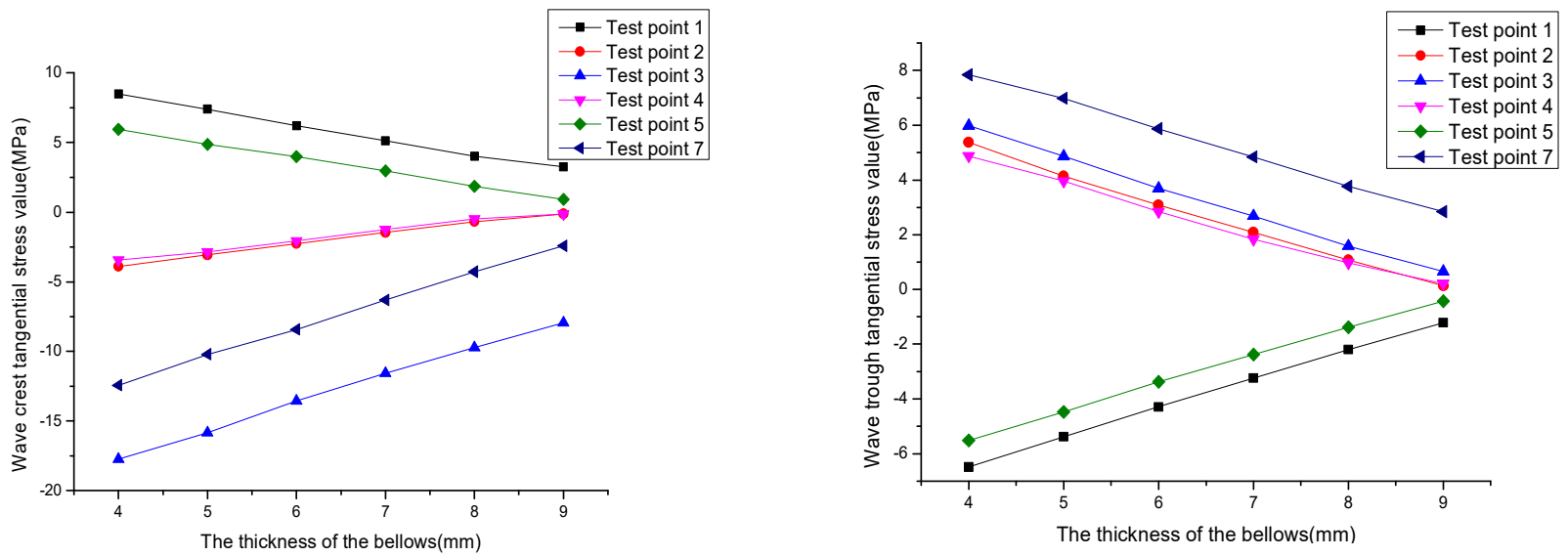

Fig 9. Figure of the tangential stress of each measuring point of the wave crest and though of different thickness

Figure 9 shows that with the increase of the thickness of the corrugated pipe, the absolute value of the tangential stress of the corrugated pipes is linearly decreasing. When the thickness of the corrugated pipes from $4 \mathrm{~mm}$ to $9 \mathrm{~mm}$, maximum reduction is achieved $78 \%$, shows that the thickness of the corrugated tubes had a greater influence on the change of the tangential stress of 
bellows. The greater the thickness of the bellows, the smaller the tangential stress value. Therefore, the stress can be controlled by increasing the thickness of the steel plate.

\section{Conclusions}

The deformation value of the bellows increases when the diameter of the bellows increases, the wavelength becomes larger or the thickness decreases. The tangential stress of the bellows will increase if the diameter becomes smaller, the wavelength becomes larger or the plate thickness becomes smaller.The corrugated pipe culvert can increase the bearing capacity of the culvert structure and reduce the deformation of the pipe culvert by adding plate thickness and using deep ripple. The larger the pipe diameter is, the more tube top load will be transferred to the surrounding soil through deformation. But in actual engineering, the size of the pipe diameter is determined according to the filling height and practical use of the steel bellows.

\section{References}

[1]Hishanl Husseill Hafez. Soil-steel structures under shallow cover [D]. Windsor Ontalrio Canada. University of Windsor.1981

[2]Esra Bayoğlu Flener. Soil-Steel Interaction of Long-Span Box Culverts-Performance during Backfilling [J]. Journal of geotechnical and geoenvironmental engineering (C) ASCE / JUNE 2010. 823-832

[3]R. W. I. Brachman. Testing and Analysis of a Deep-Corrugated Large-Span Box Culvert prior to Burial [J]. Journal of Bridge Engineering, Vol. 17, No. 1, January 1, 2012. CASCE, ISSN 1084-0702/2012/1. 81-88

[4]Hesham Mohammed. Improving the Response of Soil-Metal Structures during Construction [J]. Journal of Bridge Engineering (ASCE). 2002Y.

[5]Zhang meng dong. Dynamic and stability analysis of overburden corrugated steel plates [D]. Beijing. Beijing jiaotong university.2010.

[6]Jiang xue Mei. Experimental research and calculation analysis of the highway just corrugated arch culvert and pipe culvert [D]. Beijing. Beijing Jiao tong university.2005. 